\title{
Effects of Aqueous and Ethanol Root Extracts of Olax subscopioidea on Inflammatory Parameters in Complete Freund's Adjuvant-Collagen Type II Induced Arthritic Albino Rats
}

\author{
Nkiru Nwamaka Ezeani*, Udu Ama Ibiam, Obasi Uche Orji, Ikechuku Okorie Igwenyi, Chinyere Aloke, \\ Esther Alum, Partrick Mmaduabuchi Aja, Okechukwu Paul Chima Ugwu
}

\section{Nkiru Nwamaka Ezeani*, Udu Ama Ibiam, Obasi Uche Orji, Ikechuku Okorie Igwenyi, Chinyere Aloke, Esther Alum, Partrick Mmaduabuchi Aja, Okechukwu Paul Chima Ugwu}

Department of Biochemistry, Ebonyi State University, Abakaliki, NIGERIA.

Correspondence

\section{Dr. Nkiru Nwamaka Ezeani}

Department of Biochemistry, Ebonyi State University, Abakaliki, NIGERIA.

Phone no : 234-043-08037198460

E-mail: nk.ezeani@yahoo.com

History

- Submission Date: 12-07-2018;

- Review completed: 04-10-2018;

- Accepted Date: 15-11-2018

DOI : 10.5530/pj.2019.1.4

Article Available online

http://www.phcogj.com/v11/i1

\section{Copyright}

(C) 2019 Phcog.Net. This is an openaccess article distributed under the terms of the Creative Commons Attribution 4.0 International license.

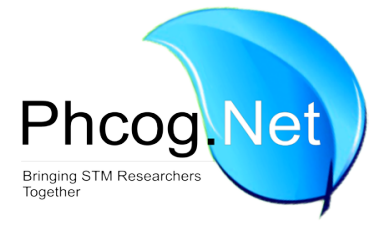

\begin{abstract}
Aim/Background: Rural and Urban dwellers in Nigeria claim to treat their arthritis with Olax subscorpioidea root extracts. One of the reasons they chose this treatment is that it is effective and cost less than orthodox drugs with their accompanying side effects. Hence the aim of this study is to investigate the anti-arthritis effects of Olax subscorpioidea Afzel ethanol and aqueous root extracts on chicken type II-Complete Freund's adjuvant (CFA) induced arthritis rat model. Materials and Method: The anti-arthritic potential of ethanol and aqueous root extracts of Olax subscorpioidea was evaluated using the chicken Type II-Complete Freund's adjuvant model in 135 female wistar albino rats. The rats were treated with aqueous and ethanol root extracts of Olax subscorpioidea at varying doses and standard indomethacine drug. Results: The ethanol and aqueous root extracts of Olax subscorpioidea showed significant anti-arthritic activity that was statistically similar to that of indomethacine. Our results suggest that the alcoholic extract of Olax subscorpioidea showed significant $(P<0.05)$ anti-arthritic potential.
\end{abstract}

Key words: Adjuvant, Arthritis, Plant Extracts, Indomethacine, Rats.

\section{INTRODUCTION}

Rheumatoid arthritis (RA) is an auto-immune disease that primarily affects joints especially the wrist and hands resulting in warm, swollen, and painful joints. ${ }^{1}$ Pain and stiffness associated with RA often worsens after rest. Rheumatoid arthritis may also affect other parts of the body, resulting in a low red blood cell count, inflammation around the lungs and inflammation around the heart. ${ }^{2}$ Prevalence data on arthritis in Africa and Nigeria in particular remain scarce however rheumatoid arthritis is affecting up to one million and three hundred thousand people in the United States alone with a low occurrence in some parts of Africa, according to current census data. The ratio of women to men having the disease is between $3: 1$ and $2: 1 .^{3}$ The disease onset is usually after 40 years of age and before 60 years of age but it can also start at any age and even affects children (juvenile rheumatoid arthritis). ${ }^{4}$ The genetic basis of the disorder suggests that multiple members can be affected in some families.

There is no cure for RA yet. Over the years, the treatment of rheumatoid arthritis optimally involves a combination of patient education, rest and exercise, joint protection, medications, and occasionally surgery. ${ }^{5}$ Some of the Medications used in the treatment of rheumatoid arthritis include Non- steroidal anti- inflammatory drug (NSAIDs) such as methotrexate, hydroxychloroquine, sulfasalazine, disease modifying anti-rheumatic drugs (DMARDs) such as TNF alpha inhibitors, IL-6 inhibitors, T-cell activation inhibitors, B-cell depleters, JAK inhibitors, immunosuppressants, and steroids (etanercept, adalimumab, certolizumab etc). these drugs show common adverse effects such as disorders of the gastro- intestinal tracks, loss of appetite, sore mouth, diarrhea, headaches and hair loss. ${ }^{6-7}$ mild skin reactions at the site of injections, infections, nausea, a rise in temperature and headaches. ${ }^{8}$ Many arthritis patients resort to the consumption of locally available herbs to manage or treat their condition cause of the high cost of orthodox drugs. They claim that these local herbs are effect in alleviating their arthritis, therefore it is becoming the general practice in our society today. Olax subscoripoidea Oliv is among the plants that have been successfully used for the treatment of arthritis by the rural dwellers. ${ }^{9}$

Olax subscorpioidea is a tree up to $10 \mathrm{~m}$ high, bole to $60 \mathrm{~cm}$ girth with long thin, drooping branches, but sometimes a many-stemmed shrub. ${ }^{10}$ Its leaf is used in as traditional medicines as pain-killers, its leaf, twig and bark are used in the treatment of arthritis,

Cite this article: Ezeani NN, Ibiam UA, Orji OU, Igwenyi IO, Aloke C, Alum E, Aja PM, Effects of Aqueous and Ethanol Root Extracts of Olax subscopioidea on Inflammatory Parameters in Complete Freund's Adjuvant-Collagen Type II Induced Arthritic Albino Rats. Pharmacog J. 2019;11(1):16-25. 
rheumatism, liver diseases, venereal diseases, febrifuges, antidotes (venomous stings, bites, etc.) The root is applied as medicine in the treatment of cutaneous, subcutaneous parasitic infection, genital stimulants/depressants. It is also used as chewing-sticks. ${ }^{11}$

There are animal disease models that exhibit the pathology of human rheumatoid disease and are therefore employed as vehicles for research on potential therapeutics designed for the management and treatment of RA. ${ }^{12}$ In a bid to evaluate the safety, effectiveness, and toxicity of new potential RA therapeutics, rodent populations which mimics human RA disease are created by collagen-induced arthritis (CIA) and complete Freund's adjuvant (CFA). They both exhibit similar effect as is seen in rheumatoid arthritis within the cells, creating synovitis and erosions. ${ }^{13}$

Olax subscorpioidea plants has been used over the years by majorly rural dwellers in the management of arthritis, however, no scientific base for this has been established or compared the effects of ethanol and aqueous extracts of the plant. Therefore the study is aimed at determining the effects of aqueous and ethanol root extracts of Olax subscorpioidea on inflammatory parameters such as weight, paw size, Erythrocyte Sedimentation Rate, C-reactive protein and Cytokines such as interleukine 1-B, interleukine-6, tumor necrosis factor, rheumatoid factor in Complete Freund's Adjuvant-Collagen Type II Induced Arthritic Rat.

\section{MATERIALS AND METHODS}

\section{Materials}

The Roots of Olax subscorpioidea was harvested from Ndi-Nwali village in Izzi Local Government Area of Ebonyi State in South-Eastern Nigeria. A botanist, Dr. (Mrs.) Kate Nnamani in the Department of Biological Sciences, Ebonyi State University, Abakaliki, authenticated the plant. Some of the plant root samples were preserved in the Department of Biological Science herbarium.

A total of one hundred and thirty-five female albino rats were purchased from the Department of Animal Science, University of Nigeria, Nsukka, Enugu State, Nigeria and were acclimatized for a period of two weeks at the Animal House of the Department of Biochemistry, Ebonyi State University, Abakaliki. The animals were kept in cages and fed on commercial rat feed and were allowed access to clean water. The weight of the test rats were measured daily.

\section{Methods}

\section{Preparation of the plant extracts}

The roots of Olax subscoipioidea were washed under tap water and air dried in a suitable environment. The roots were ground using laboratory milling machine and sifted using $0.25 \mathrm{~mm}$ sieve. Exactly $800 \mathrm{~g}$ of the powdered root sample of Olax suscorpioidea were soaked in 2L each of ethanol and deionized water for $48 \mathrm{~h}$, filtered with a clean white cloth and concentrated using a water bath at $35^{\circ} \mathrm{C}$ until the solvents were completely removed. Extracts obtained were used for various analyses.

\section{Induction of arthritis in albino rats}

Pearson's method of induction of arthritis in rats was applied (1956). ${ }^{14}$ Briefly, $0.1 \mathrm{ml}$ of chicken Type II collagen-complete Freund's adjuvant (CFA) was injected into the left hind paw of the rats (The constituents of the CFA are heat killed Mycobacterium tuberculosis and sterile paraffin oil $(10 \mathrm{mg} / \mathrm{ml})$. The degree of hind paw swelling in each animal was determined using a calibrated automated veneer caliper twice weekly throughout the duration of the study prior to and after the administration of the adjuvant. Those rats with elevated level of inflammatory biomarkers when compared to the control were therefore considered to have arthritis and were used for subsequent experiments. The weights of rats were taken daily throughout the study duration.

\section{Treatment of Arthritic rats with plant extracts}

Female albino rats weighing between 150-200 g were used for this work. The animals were sub divided into 9 groups with 15 animals in each group. Group I served as negative control (without induction of arthritis and treatment) and received $5 \mathrm{ml} / \mathrm{kg}$ normal saline; Group 2 was induced with arthritis but without treatment. It served as the positive control and received $5 \mathrm{ml} / \mathrm{kg}$ normal saline; Group 3 was administered $10 \mathrm{mg} / \mathrm{kg}$ indomethacine (standard control), Groups 4-6 were induced with arthritis and were treated with Olax subscopioidea aqueous root extractat doses of 400, 600 and $800 \mathrm{mg} / \mathrm{kg}$ body weight, respectively, from day ten after induction till the end of the study; Groups 7-9 were induced with arthritis and received Olax subscorpioidea ethanol root extract at 400, 600 and $800 \mathrm{mg} / \mathrm{kg}$ body weight, respectively from day 10 after induction till the end of the study. Various changes in the body weight and inflammatory index were measured daily. Three albino rats from each group were sacrificed on days 10, 18, 25 and 32 and blood samples were collected in plain tubes for serum separation

\section{Phytochemical screening}

The aqueous and ethanol extracts of Olax subscorpioidea was tested using standard procedures to identify the presence of Tannin, flavonoids, terpenoids, steroids, alkaloids saponin, phenol and carotenoids. ${ }^{15-17}$

\section{Estimation of inflammatory parameters}

Inflammatory parameters determined were erythrocyte sedimentation rate (ESR), C-reactive protein CRP, Rheumatoid factor (RF) and cytokines such as IL-1B, IL-6 and TNF were determined. ${ }^{18-21}$

\section{Statistical Analysis}

The basic statistics, means, standard deviation and ranges of the measured parameters were estimated using Statistical Analysis System (SAS) windows version 9.0. Data expressed was done as means \pm SD of 15 replicates. Values were considered statistically significant at $P<0.05$.

Table 1: Percentage Yields of ethanol and aqueous extracts of Olax subscorpiodea roots.

\begin{tabular}{ccc} 
Sample & \multicolumn{2}{c}{ Yield } \\
& Aqueous extract & ethanol extract \\
\hline Olax subsorpioidea & $10.68 \%$ & $9.5 \%$ \\
\hline
\end{tabular}

Table 2: Percentage phytochemical constituent of ethanol and aqueous extracts of Olax subscorpioidea roots.

\begin{tabular}{ccc}
\hline & Aqueous extract (\%) & $\begin{array}{c}\text { Ethanol extract } \\
\text { (\%) }\end{array}$ \\
\hline Tannin & 4.72 & 4.91 \\
Terpenoids & 0.285 & 3.32 \\
Steroids & 2.12 & 3.58 \\
Alkaloids & 2.10 & 3.58 \\
Saponin & 4.22 & 0.02 \\
Phenol & 3.57 & 6.7 \\
Flavonoids & 2.35 & 3.45 \\
Carotenoids & 1.12 & 2.23 \\
\hline
\end{tabular}


Table 3: Effect of Olax subscorpioidea aqueous and ethanol root extracts on weight of adjuvant-induced arthritic rats

\begin{tabular}{|c|c|c|c|c|}
\hline Treatment & $W k 1(g)$ & Wk2(g) & Wk3(g) & Wk4(g) \\
\hline 1 & $180.60 \pm 3.84^{\mathrm{a}}$ & $182.00 \pm 6.30^{c, e, d}$ & $184.33 \pm 6.15^{c, d}$ & $191.00 \pm 6.78^{c}$ \\
\hline 2 & $168.80 \pm 9.59^{\mathrm{b}, \mathrm{a}, \mathrm{c}}$ & $167.87 \pm 4.09^{g, \mathrm{I}, \mathrm{h}}$ & $161.33 \pm 4.72^{\mathrm{i}}$ & $155.25 \pm 3.59^{f}$ \\
\hline 3 & $166.60 \pm 10.59^{\mathrm{b}, \mathrm{a}, \mathrm{c}}$ & $176.37 \pm 6.16^{\text {c,fe, }, \mathrm{d}}$ & $182.50 \pm 7.45^{\mathrm{e}, \mathrm{d}}$ & $190.50 \pm 5.97^{c}$ \\
\hline 4 & $163.10 \pm 18.07^{c}$ & $172.00 \pm 12.94^{g, f, \mathrm{I}, \mathrm{h}}$ & $175.33 \pm 12.69^{\mathrm{h}, \mathrm{ge}}$ & $193.75 \pm 3.40^{c}$ \\
\hline 5 & $160.70 \pm 11.42^{c}$ & $166.87 \pm 8.80^{* \text { t,h }}$ & $177.50 \pm 8.39^{\mathrm{eg}, \mathrm{f}}$ & $179.75 \pm 12.58^{\mathrm{e}}$ \\
\hline 6 & $163.00 \pm 17.08^{c}$ & $166.00 \pm 5.53^{\mathrm{i}}$ & $171.00 \pm 7.94^{\mathrm{h}}$ & $178.25 \pm 8.72^{\mathrm{e}}$ \\
\hline 7 & $160.20 \pm 9.37^{\mathrm{b}, \mathrm{a}, \mathrm{c}}$ & $182.12 \pm 10.36^{\mathrm{c}, \mathrm{b}}$ & $189.33 \pm 15.85^{\mathrm{c} b}$ & $203.25 \pm 14.66^{b}$ \\
\hline 8 & $165.00 \pm 14.51^{\mathrm{b}, \mathrm{a}, \mathrm{c}}$ & $174.12 \pm 9.85^{\mathrm{g}, \mathrm{fe}, \mathrm{d}}$ & $180.00 \pm 12.52^{e, d, f}$ & $191.25 \pm 4.03^{c}$ \\
\hline 9 & $169.80 \pm 6.03^{\mathrm{a}}$ & $194.75 \pm 7.15^{\mathrm{a}}$ & $201.17 \pm 8.68^{\mathrm{a}}$ & $212.00 \pm 9.83^{\mathrm{a}}$ \\
\hline
\end{tabular}

Table 4: Effect of Olax subscorpioidea aax subscorpioidea aqueous and ethanol root extracts on paw size (inflammation) of adjuvantinduced arthritic rats treated.

\begin{tabular}{|c|c|c|c|c|c|}
\hline Treatments & Before (mm) & week $1(\mathrm{~mm})$ & week $2(\mathrm{~mm})$ & week $3(\mathrm{~mm})$ & week 4 (mm) \\
\hline 1 & $2.73 \pm 0.02^{\mathrm{a}}$ & $2.73 \pm 0.20^{\mathrm{e}}$ & $2.73 \pm 0.02^{\mathrm{g}}$ & $2.73 \pm 0.01^{\mathrm{e}}$ & $2.73 \pm 0.01^{\mathrm{h}, \mathrm{g}}$ \\
\hline 2 & $2.72 \pm 0.01^{\mathrm{a}}$ & $5.37 \pm 0.08^{\mathrm{a}}$ & $6.52 \pm 0.23^{\mathrm{a}}$ & $7.31 \pm 0.07^{\mathrm{a}}$ & $7.79 \pm 0.04^{\mathrm{a}}$ \\
\hline 3 & $2.70 \pm 0.04^{\mathrm{a}}$ & $4.53 \pm 0.51^{\mathrm{b}, \mathrm{d}, \mathrm{c}}$ & $3.76 \pm 0.69^{f}$ & $2.79 \pm 0.23^{\mathrm{e}}$ & $2.68 \pm 0.12^{\mathrm{h}}$ \\
\hline 4 & $2.68 \pm 0.07^{\mathrm{a}}$ & $5.06 \pm 0.39^{\mathrm{b}, \mathrm{a}}$ & $4.80 \pm 0.11^{\mathrm{c}, \mathrm{b}}$ & $3.87 \pm 0.12^{\mathrm{c}, \mathrm{b}, \mathrm{d}}$ & $2.93 \pm 0.03^{\text {fh, }, \mathrm{eg}}$ \\
\hline 5 & $2.72 \pm 0.04^{\mathrm{a}}$ & $4.77 \pm 0.13^{\mathrm{b}, \mathrm{a}}$ & $4.63 \pm 0.21^{\mathrm{c}, \mathrm{b}, \mathrm{d}}$ & $3.77 \pm 0.06^{\mathrm{c}, \mathrm{b}, \mathrm{d}}$ & $2.96 \pm 0.10^{\mathrm{fhhe,g, \textrm {d }}}$ \\
\hline 6 & $2.71 \pm 0.11^{\mathrm{a}}$ & $4.67 \pm 0.14^{\mathrm{b}, \mathrm{a}, \mathrm{c}}$ & $4.58 \pm 0.15^{c, b, d}$ & $3.61 \pm 0.09^{\mathrm{c}, \mathrm{d}}$ & $2.88 \pm 0.39^{\text {fth,g }}$ \\
\hline 7 & $2.71 \pm 0.01^{\mathrm{a}}$ & $4.96 \pm 0.55^{\mathrm{b}, \mathrm{a}}$ & $4.85 \pm 0.31^{\mathrm{b}}$ & $4.18 \pm 0.20^{\mathrm{b}}$ & $3.49 \pm 0.24^{\mathrm{b}}$ \\
\hline 8 & $2.72 \pm 0.02^{\mathrm{a}}$ & $4.77 \pm 0.47^{\mathrm{b}, \mathrm{a}, \mathrm{c}}$ & $4.58 \pm 0.27^{c, b, d}$ & $3.87 \pm 0.39^{\mathrm{c}, \mathrm{b}, \mathrm{d}}$ & $3.18 \pm 0.11^{f, c, e, b, d}$ \\
\hline 9 & $2.73 \pm 0.03^{\mathrm{a}}$ & $4.75 \pm 0.26^{\mathrm{b}, \mathrm{a}, \mathrm{c}}$ & $4.22 \pm 0.23^{\mathrm{e}, \mathrm{d}}$ & $3.62 \pm 0.36^{\mathrm{cd} d}$ & $3.28 \pm 0.14^{\mathrm{c}, \mathrm{b}, \mathrm{d}}$ \\
\hline
\end{tabular}

Table 5: Effect of Olax subscorpioidea aqueous and ethanol root extracts on C-RP level of adjuvant induced arthritic rats treated.

\begin{tabular}{|c|c|c|c|c|}
\hline Treatments & DAY10(mg/dl) & DAY18 (mg/dl) & DAY $25(\mathrm{mg} / \mathrm{dl})$ & DAY32 (mg/dl) \\
\hline 1 & $4.22 \pm 0.15^{\mathrm{f}}$ & $4.35 \pm 0.86^{\mathrm{i}}$ & $4.96 \pm 0.01^{\mathrm{h}}$ & $4.36 \pm 0.01^{\mathrm{f}}$ \\
\hline 2 & $10.34 \pm 0.91^{\mathrm{a}}$ & $12.61 \pm 0.35^{\mathrm{a}}$ & $17.51 \pm 0.17^{\mathrm{a}}$ & $21.42 \pm 1.49^{\mathrm{a}}$ \\
\hline 3 & $7.52 \pm .012^{\mathrm{e}}$ & $7.41 \pm 0.78^{g, f}$ & $5.36 \pm 0.04^{\mathrm{g}}$ & $4.45 \pm 0.04^{\mathrm{f}}$ \\
\hline 4 & $8.16 \pm 0.21^{\mathrm{cd}}$ & $7.84 \pm 0.12^{\mathrm{e}, \mathrm{f,d}}$ & $6.62 \pm 0.69^{\mathrm{fe,d}}$ & $6.57 \pm 0.69^{b}$ \\
\hline 5 & $8.11 \pm 0.13^{d}$ & $7.86 \pm 0.09^{c, e, d}$ & $6.40 \pm 0.02^{\mathrm{f}, \mathrm{e}}$ & $5.74 \pm 0.43^{\mathrm{ce,ed}}$ \\
\hline 6 & $8.31 \pm 0.11^{\mathrm{c}, \mathrm{b}, \mathrm{d}}$ & $6.92 \pm 0.00^{\mathrm{h}}$ & $5.72 \pm 0.07^{\mathrm{g}}$ & $5.24 \pm 0.27^{\mathrm{e}}$ \\
\hline 7 & $8.37 \pm 0.05^{\mathrm{cb}, \mathrm{d}}$ & $8.38 \pm 0.01^{b}$ & $6.98 \pm 0.00^{\mathrm{d}}$ & $6.65 \pm 0.15^{b}$ \\
\hline 8 & $8.11 \pm 0.12^{\mathrm{d}}$ & $7.80 \pm 0.35^{\mathrm{e}, \mathrm{f}}$ & $7.08 \pm 0.15^{\mathrm{c}, \mathrm{b}}$ & $6.42 \pm 0.06^{\mathrm{c}, \mathrm{b}}$ \\
\hline 9 & $8.62 \pm 0.18^{b}$ & $7.75 \pm 0.33^{\mathrm{e}, \mathrm{f}}$ & $6.61 \pm 0.06^{\mathrm{fe}, \mathrm{d}}$ & $5.58 \pm 0.35^{\mathrm{e}, \mathrm{d}}$ \\
\hline
\end{tabular}


Ezeani, et al:: Aqueous and Ethanol Extracts and Olax subscorpioidea Suppresses Inflammatory Parameters in Athritic Rats

Table 6: Effect of Olax subscorpioidea aqueous and ethanol root extracts on rheumatoid factor level of adjuvant induced arthritic rats treated

\begin{tabular}{ccccc}
\hline Treatments & DAY10 (IU/ml)) & DAY18 (IU/ml)) & DAY25 (IU/ml)) & DAY32 (IU/mI)) \\
\hline 1 & $26.42 \pm 0.99^{\mathrm{f}}$ & $25.06 \pm 0.46^{\mathrm{d}}$ & $27.31 \pm 0.46^{\mathrm{f}}$ & $27.96 \pm 0.05^{\mathrm{b}, \mathrm{c}}$ \\
2 & $52.64 \pm 0.35^{\mathrm{a}}$ & $58.41 \pm 0.64^{\mathrm{a}}$ & $62.23 \pm 2.62^{\mathrm{a}}$ & $71.28 \pm 1.01^{\mathrm{a}}$ \\
3 & $38.99 \pm 0.88^{\mathrm{e}}$ & $32.61 \pm 1.80^{\mathrm{c}}$ & $29.48 \pm 1.29^{\mathrm{e}}$ & $27.64 \pm 1.41^{\mathrm{b}, \mathrm{c}}$ \\
4 & $42.22 \pm 1.17^{\mathrm{c}}$ & $40.72 \pm 0.07^{\mathrm{b}}$ & $34.37 \pm 1.41^{\mathrm{c}}$ & $27.74 \pm 1.58^{\mathrm{b}, \mathrm{c}}$ \\
5 & $41.99 \pm 0.19^{\mathrm{d}, \mathrm{c}}$ & $40.21 \pm 0.40^{\mathrm{b}}$ & $34.36 \pm 0.33^{\mathrm{c}}$ & $27.88 \pm 0.78^{\mathrm{b}, \mathrm{c}}$ \\
6 & $40.92 \pm 0.26^{\mathrm{d}, \mathrm{c}}$ & $40.36 \pm 1.41^{\mathrm{b}}$ & $34.27 \pm 1.96^{\mathrm{c}}$ & $27.03 \pm 0.21^{\mathrm{b}, \mathrm{c}}$ \\
8 & $43.65 \pm 1.40^{\mathrm{c}}$ & $41.65 \pm 2.84^{\mathrm{b}}$ & $33.37 \pm 0.01^{\mathrm{c,d}}$ & $27.26 \pm 4.43^{\mathrm{b}, \mathrm{c}}$ \\
9 & $42.60 \pm 0.41^{\mathrm{c}}$ & $40.64 \pm 1.06^{\mathrm{b}}$ & $32.43 \pm 0.02^{\mathrm{c} . \mathrm{d}}$ & $27.10 \pm 1.34^{\mathrm{b}, \mathrm{c}}$ \\
\hline
\end{tabular}

Table 7: Effect of Olax subscorpioidea aqueous and ethanol root extracts on ESR level of adjuvant induced arthritic rats.

\begin{tabular}{|c|c|c|c|c|}
\hline Treatments & DAY $10(\mathrm{~mm} / \mathrm{hr})$ & DAY $18(\mathrm{~mm} / \mathrm{hr})$ & DAY $25(\mathrm{~mm} / \mathrm{hr})$ & DAY $32(\mathrm{~mm} / \mathrm{hr})$ \\
\hline 1 & $3.68 \pm 0.07^{g}$ & $3.53 \pm 0.01^{\mathrm{f}}$ & $3.42 \pm 0.15^{\mathrm{g}}$ & $3.35 \pm 0.24^{\mathrm{h}}$ \\
\hline 2 & $7.57 \pm 0.21^{\mathrm{b}, \mathrm{a}, \mathrm{c}}$ & $8.11 \pm 1.02^{\mathrm{a}}$ & $10.39 \pm 0.02^{\mathrm{a}}$ & $11.82 \pm 0.15^{\mathrm{a}}$ \\
\hline 3 & $6.58 \pm 0.45^{\star f}$ & $5.15 \pm 0.05^{\mathrm{e}}$ & $4.86 \pm 0.18^{f}$ & $3.81 \pm 0.01^{\mathrm{g}}$ \\
\hline 4 & $7.37 \pm 0.08^{\mathrm{b}, \mathrm{c}}$ & $6.69 \pm 0.12^{\mathrm{b}}$ & $6.35 \pm 0.29^{b}$ & $4.49 \pm 0.12^{c}$ \\
\hline 5 & $7.77 \pm 0.09^{\mathrm{a}}$ & $6.68 \pm 0.03^{c}$ & $5.55 \pm 0.14^{\mathrm{d}}$ & $4.27 \pm 0.06^{\mathrm{d}, \mathrm{e}}$ \\
\hline 6 & $6.97 \pm 0.01^{e, d}$ & $5.51 \pm 0.18^{\mathrm{d}, c, e}$ & $5.37 \pm 0.39^{\mathrm{e}, \mathrm{d}}$ & $4.16 \pm 0.42^{\mathrm{e}, \mathrm{f}}$ \\
\hline 7 & $7.68 \pm 0.12^{\mathrm{b}, \mathrm{a}}$ & $6.68 \pm 0.11^{b}$ & $6.35 \pm 0.30^{\mathrm{b}}$ & $4.20 \pm 0.11^{\mathrm{d}, \mathrm{e}, \mathrm{f}}$ \\
\hline 8 & $7.26 \pm 0.09^{\mathrm{d}, \mathrm{c}}$ & $5.67 \pm 0.03^{\mathrm{d}, \mathrm{c}}$ & $5.53 \pm 0.15^{\mathrm{d}}$ & $3.80 \pm 0.01^{\mathrm{g}}$ \\
\hline 9 & $6.82 \pm 0.00^{\mathrm{e}, \mathrm{f}}$ & $5.46 \pm 0.23^{\mathrm{d}, \mathrm{c}, \mathrm{e}}$ & $5.37 \pm 0.25^{\mathrm{e}, \mathrm{d}}$ & $3.70 \pm 0.26^{\mathrm{g}}$ \\
\hline
\end{tabular}

Table 8: Effect of Olax subscorpioidea aqueous and ethanol root extracts on TNF-a level of adjuvant induced arthritic rats.

\begin{tabular}{ccccc}
\hline Treatments & DAY 10 & DAY 18 & DAY 25 & DAY 32 \\
\hline 1 & $(\mathrm{pg} / \mathrm{ml})$ & $(\mathrm{pg} / \mathrm{ml})$ & $(\mathrm{pg} / \mathrm{ml})$ & $(\mathrm{pg} / \mathrm{ml})$ \\
\hline 2 & $198 \pm 10.73^{\mathrm{b}}$ & $200 \pm 12.02^{\mathrm{k}}$ & $197 \pm 13.03^{\mathrm{i}}$ & $198 \pm 11.01^{\mathrm{g}}$ \\
3 & $480 \pm 18.08^{\mathrm{a}}$ & $760 \pm 16.71^{\mathrm{a}}$ & $800 \pm 17.15^{\mathrm{a}}$ & $820 \pm 15.89^{\mathrm{a}}$ \\
4 & $470 \pm 11.11^{\mathrm{a}}$ & $350 \pm 10.80^{\mathrm{j}}$ & $320 \pm 9.24^{\mathrm{e}}$ & $205 \pm 8.01^{\mathrm{e}, \mathrm{f}}$ \\
5 & $477 \pm 14.00^{\mathrm{a}}$ & $440 \pm 12.14^{\mathrm{d}}$ & $320 \pm 8.50^{\mathrm{e}}$ & $218 \pm 11.08^{\mathrm{c}, \mathrm{b}}$ \\
6 & $478 \pm 13.03^{\mathrm{a}}$ & $410 \pm 12.12^{\mathrm{g}}$ & $310 \pm 9.54^{\mathrm{f}}$ & $208 \pm 10.23^{\mathrm{e}, \mathrm{f}}$ \\
7 & $474 \pm 12.09^{\mathrm{a}}$ & $380 \pm 10.00^{\mathrm{i}}$ & $300 \pm 12.00^{\mathrm{g}}$ & $206 \pm 9.18^{\mathrm{e}, \mathrm{f}}$ \\
\hline 8 & $475 \pm 18.07^{\mathrm{a}}$ & $445 \pm 12.94^{\mathrm{c}, \mathrm{d}}$ & $323 \pm 12.69^{\mathrm{e}}$ & $216 \pm 3.40^{\mathrm{c}}$ \\
\hline 9 & $473 \pm 11.42^{\mathrm{a}}$ & $415 \pm 8.81^{\mathrm{f}, \mathrm{g}}$ & $307 \pm 8.39^{\mathrm{f}}$ & $210 \pm 12.58^{\mathrm{e}, \mathrm{d}}$ \\
& $470 \pm 17.08^{\mathrm{a}}$ & $385 \pm 5.53^{\mathrm{i}}$ & $292 \pm 7.94^{\mathrm{h}}$ & $204 \pm 8.72^{\mathrm{f}}$
\end{tabular}

Table 9: Effect of Olax subscorpioidea aqueous and ethanol root extracts on interleukin-6 level of adjuvant-induced arthritic rats.

\begin{tabular}{ccccc}
\hline Treatments & $\begin{array}{c}\text { DAY 10 } \\
(\mathrm{pg} / \mathrm{ml})\end{array}$ & $\begin{array}{c}\text { DAY 18 } \\
(\mathrm{pg} / \mathrm{ml})\end{array}$ & $\begin{array}{c}\text { DAY 25 } \\
(\mathrm{pg} / \mathrm{ml})\end{array}$ & $\begin{array}{c}\text { DAY 32 } \\
(\mathrm{pg} / \mathrm{ml})\end{array}$ \\
\hline 1 & $180 \pm 3.84^{\mathrm{b}}$ & $188 \pm 6.30^{\mathrm{i}}$ & $185 \pm 6.15^{\mathrm{k}}$ & $187 \pm 6.78^{\mathrm{h}}$ \\
\hline 2 & $420 \pm 9.59 \mathrm{~b}$ & $657 \pm 4.09^{\mathrm{a}}$ & $789 \pm 4.72^{\mathrm{a}}$ & $811 \pm 3.59^{\mathrm{a}}$ \\
\hline 3 & $410 \pm 10.59^{\mathrm{a}}$ & $325 \pm 6.16^{\mathrm{h}}$ & $315 \pm 7.458^{\mathrm{j}}$ & $205 \pm 5.97^{\mathrm{g}}$ \\
4 & $411 \pm 9.37^{\mathrm{a}}$ & $370 \pm 10.36^{\mathrm{c}}$ & $335 \pm 15.85^{\mathrm{g}, \mathrm{f}}$ & $230 \pm 14.66^{\mathrm{c} . \mathrm{d}}$ \\
\hline 5 & $410 \pm 14.51^{\mathrm{a}}$ & $340 \pm 9.85^{\mathrm{f}}$ & $330 \pm 12.52^{\mathrm{ghh}}$ & $224 \pm 4.03^{\mathrm{e}}$ \\
7 & $409 \pm 6.03^{\mathrm{a}}$ & $351 \pm 7.15^{\mathrm{g}}$ & $320 \pm 8.68^{\mathrm{I}, \mathrm{j}}$ & $214 \pm 9.83^{\mathrm{f}}$ \\
\hline 8 & $408 \pm 13.25^{\mathrm{a}}$ & $360 \pm 12.10^{\mathrm{e}, \mathrm{d}}$ & $330 \pm 12.33^{\mathrm{g}, \mathrm{h}}$ & $238 \pm 11.15^{\mathrm{b}}$ \\
\hline 9 & $411 \pm 12.21^{\mathrm{a}}$ & $345 \pm 10.45^{\mathrm{f}}$ & $325 \pm 14.03^{\mathrm{I}, \mathrm{h}}$ & $220 \pm 10.00^{\mathrm{e}}$ \\
\hline
\end{tabular}


Ezeani, et al.: Aqueous and Ethanol Extracts and Olax subscorpioidea Suppresses Inflammatory Parameters in Athritic Rats

Table 10: Effect of Olax subscorpioidea aqueous and ethanol root extracts on IL-1 $\beta$ level of adjuvant-induced arthritic rats.

\begin{tabular}{ccccc}
\hline $\begin{array}{c}\text { Treat- } \\
\text { ments }\end{array}$ & DAY $10(\mathrm{pg} / \mathrm{ml})$ & DAY 18 & $\begin{array}{l}\text { Y } 25(\mathrm{pg} / \\
\mathrm{ml})\end{array}$ & $\begin{array}{l}\text { DAY } 32(\mathrm{pg} / \\
\mathrm{ml})\end{array}$ \\
\hline 1 & $196 \pm 10.71^{\mathrm{e}}$ & $194 \pm 11.34^{\mathrm{f}}$ & $190 \pm 1.70^{\mathrm{h}}$ & $194 \pm 0.17^{\mathrm{e}, \mathrm{f}}$ \\
\hline 2 & $258 \pm 13.79^{\mathrm{b}, \mathrm{a}}$ & $470 \pm 10.00^{\mathrm{a}}$ & $590 \pm 0.21^{\mathrm{a}}$ & $650 \pm 0.76^{\mathrm{a}}$ \\
3 & $242 \pm 7.47^{\mathrm{d}, \mathrm{c}}$ & $220 \pm 13.61^{\mathrm{c}, \mathrm{e}, \mathrm{d}}$ & $212 \pm 4.27^{\mathrm{fe,d}}$ & $198 \pm 1.22^{\mathrm{e}, \mathrm{d}}$ \\
4 & $255 \pm 12.35^{\mathrm{b}, \mathrm{a}, \mathrm{c}}$ & $227 \pm 13.98^{\mathrm{c}, \mathrm{b}}$ & $217 \pm 3.66^{\mathrm{c}, \mathrm{b}, \mathrm{d}}$ & $200 \pm 0.49^{\mathrm{d}}$ \\
5 & $259 \pm 10.01^{\mathrm{b}, \mathrm{a}}$ & $220 \pm 12.55^{\mathrm{c}, \mathrm{e}, \mathrm{d}}$ & $215 \pm 2.18^{\mathrm{ce}, \mathrm{d}}$ & $192 \pm 7.74^{\mathrm{f}}$ \\
6 & $248 \pm 10.01^{\mathrm{b}, \mathrm{d}, \mathrm{c}}$ & $220 \pm 12.55^{\mathrm{c}, \mathrm{e}, \mathrm{d}}$ & $210 \pm 2.18^{\mathrm{f}, \mathrm{e}}$ & $190 \pm 7.74^{\mathrm{f}}$ \\
7 & $250 \pm 9.37^{\mathrm{b}, \mathrm{d}, \mathrm{c}}$ & $220 \pm 3.36^{\mathrm{c}, \mathrm{e}, \mathrm{d}}$ & $210 \pm 8.85^{\mathrm{f}, \mathrm{e}}$ & $201 \pm 4.66^{\mathrm{d}}$ \\
\hline 8 & $254 \pm 4.51^{\mathrm{b}, \mathrm{d}, \mathrm{a}, \mathrm{c}}$ & $216 \pm 9.85^{\mathrm{e}}$ & $208 \pm 6.25^{\mathrm{f}}$ & $193 \pm 4.03^{\mathrm{e}, \mathrm{f}}$ \\
9 & $247 \pm 6.03^{\mathrm{b}, \mathrm{d}, \mathrm{c}}$ & $214 \pm 7.15^{\mathrm{e}}$ & $202 \pm 8.68^{\mathrm{g}}$ & $191 \pm 9.83^{\mathrm{f}}$ \\
\hline
\end{tabular}

\section{RESULTS}

The results of the percentage yield of ethanol and aqueous root extracts ( Table 1) showed that the percentage yield of Olax subscorpiodea ethanol extract was $9.5 \%$ while its aqueous extract yield was $10.68 \%$ while the result of the quantitative phytochemical composition of the plant root extracts at varying amounts is shown in Table 2.

The effect of the administration of Olax subscorpiodea ethanol and aqueous root extracts on the weight of rats as presented in Table 3 shows the ameliorator effect of indomethacine and Olax subscorpoidea aqueous and ethanol root extracts on the weight of the treated arthritic rats when compared to the arthritic but untreated group and the normal control. The weight of the arthritic rats reduced significantly $(P<0.05)$. the administration of Olax subscorpioidea aqueous and ethanol root extracts on the arthritic rats however reversed the effect of adjuvant on the weight of the rats to normal while the weight of untreated arthritic rats continued to decrease significantly $(P<0.05)$ until the end of the study period.

The effect of Olax subscorpioidea ethanol and aqueous root extracts on paw size (inflammation) of rats (Table 4) shows the anti-inflammatory effect of indomethacine and Olax subscorpioidea ethanol and aqueous root extracts at 400,600 and $800 \mathrm{mg} / \mathrm{kg}$ bd wt respectively, on the changes in paw edema of untreated arthritic rats and treated animals. There paw size increased significantly $(P<0.05)$ and redness developed within $48 \mathrm{hr}$ period in the feet pad of the animals administered with the adjuvant. The administration of Olax subscorpioidea aqueous and ethanol root extracts at different doses showed a marked reduction in paw size while the paw size of arthritic untreated albino rats increased significantly $(P<0.05)$.

The result of C-reactive protein is presented in Table 5 . The $\mathrm{C}$-reactive protein levels in the arthritic untreated rats significantly $(P<0.05)$ increased with the highest value observed on day 32 . However, treatment of the arthritic rats with root extracts of Olax subscorpioidea aqueous and $800 \mathrm{mg} / \mathrm{kg}$ b.w doses, caused a significant $(P<0.05)$ reduction of C-RP levels relative to the levels found in the normal rats. The effect was both dose and time-dependent. There was no significantly difference between the effects due to the solvent used.

The result of the effect of Olax subscorpioidea ethanol and aqueous root extracts on Rheumatoid factor (RF) of rats is presented in Table 6. RF count was found to be significantly $(p<0.05)$ higher in the arthritic rat groups. Treatment with Olax subscorpiodea ethanol and aqueous root extracts at 400, 600 and $800 \mathrm{mg} / \mathrm{kg}$ bd wt however caused a significant reversal of RF value back to normal as is found in the normal rat group.

Table 7 revealed the effect of Olax subscorpioidea aqueous and ethanol root extracts on ESR levels in the arthritic rats. The ESR level in arthritic rats was significantly $(P<0.05)$ higher relative to the normal control. However treatment with standard drug and Olax subscorpioidea aqueous and ethanol root extracts at different doses administered in this study significantly caused a reversal of ESR value close to the levels of the normal control groups in a dose and time-dependent manner. Treatment with 600 and $800 \mathrm{mg} / \mathrm{kg}$ Olax subscorpioidea ethanol extract showed a significantly $(P<0.05)$ higher effect than other plant extract dose treated group The results of cytokine levels are presented in Tables $8-10$. The result shows the levels of Serum cytokines measured in the arthritic and non arthritic samples. In comparison to the normal control group, the arthritic animal groups that were not administered the plant extracts had a significant $(P<0.05)$ higher values of TNF- $\alpha$, IL-1 $\beta$ and IL-6 levels. The measured cytokine concentration were observed to have reduced $(P<0.05)$ following the administration of plant extracts to the arthritic rats. This ameliorative effect of the plant extracts was comparable to those of the normal control group. The values of TNF- $\alpha$, IL-1B and IL- 6 in the untreated arthritic rats continued to increase significantly $(P<0.05)$ till the end of the study period. Within the treatment groups, GP 10 rats which were administered $800 \mathrm{mg} / \mathrm{kg}$ Olax subscorpiodea ethanol extract, were found to contain cytokine levels close to the values found in the indomethacine treated group; thus at extract dose of $800 \mathrm{mg} / \mathrm{kg} \mathrm{b.w}$, the effect was similar to that of the standard drug.

\section{DISCUSSION}

Plants have been used in the preparation of traditional medicines all over the World for so many years now and yet remain as the major source of important plant chemicals for drug development. ${ }^{22}$ The application of medicinal plants like Olax subscopioidea in the management of rheumatoid arthritis is associated with its use by rural dwellers in Nigeria. ${ }^{23}$

Rheumatoid arthritis is an autoimmune disease in which the immune system which usually fights infections now attacks the cells that surround the joints causing swelling of the joints, joint stiffness and pain, leading to damage to the joint itself, the cartilage and nearby bones. ${ }^{24}$

There is yet no cure for rheumatoid arthritis. ${ }^{25}$ Presently, NSAIDs as well as DMARDs are used to manage rheumatoid arthritis patients. These drugs lower the associated pain and inflammation and also decrease the progression of the disease. ${ }^{26}$ Due to the adverse effects of NSAIDS and DEMARDS use and the cost of the drugs, more number of arthritic patients demand and prefer alternative medicines, hence the use of herbal preparations. ${ }^{27}$ The systemic injection of chicken type II collagen -CFA in experimental animals like rats, models human arthritis, resulting in polyarthritis and systemic disease that mimics transformations as is found in human rheumatoid arthritis. ${ }^{28}$ Some inflammatory parameters were determined to ascertain the effectiveness of this plant.

The results presented in Table 3-10 showed that rheumatoid arthritis was induced in rats within a period of 10 days by administering chicken type 11 collagen-complete Freund's adjuvant. The report by Bendele ${ }^{29}$ is in agreement with our findings. He reported that polyarthritis results from the administration of chicken Type 11 collagen-complete Freund's adjuvant was characterized by marked cartilage destruction the deposition of immune complex on articular surfaces, bone resorption and periosteal proliferation, and moderate to marked synovitis. Induction of arthritis condition caused significant $(P<0.05)$ weight loss in rats. Our findings are agreement with the report of mondal et al..$^{30}$ This weight loss could be associated with reduction in food intake by the experimental animals and with increased synthesis of TNFa and IL-1 by splenocytes. ${ }^{31}$ 
Weight loss has been reported to be a marker for an upsurge in the synthesis of TNF- $a$ and interleukin-1 which are pro-inflammatory cytokines. The association of cytokines such as TNFa and IL-1 synthesis with loss of weight in adjuvant arthritis suggests that inflammatory cachexia is cytokine-driven. TNF- $\alpha$ and IL-1 production by peripheral blood mononuclear cells (PBMC) in humans was associated with increased resting energy expenditure. ${ }^{31}$

It has also been reported body weight loss in adjuvant induced arthritic rats may be caused by muscle wasting in experimental arthritis which is seen as an increased breakdown of protein by the ubiquitin-proteosome proteolytic pathway. ${ }^{32} \mathrm{~A}$ rapid increase in leptin level just within twentyfour hours of injecting of CFA in rats leading to anorexia and loss of weight is seen in CFA induced arthritic rats. ${ }^{32}$ The administration of Olax subscorpioidea aqueous and ethanol root extracts at different doses ameliorated the effect of the adjuvant on the weight of the arthritic rats.The ameliorative effect of these extracts may have been due to the presence of phytochemical constituents like alkaloids, flavonoids and terpenoids. These phytochemicals may have exerted this effect by inhibiting enzymes such as tyrosine protein kinase that induces anti-proliferative effects on M-CSF-activated macrophages. These enzymes are involved in signaling transduction and cell activation processes ( $\mathrm{T}$ cell, B lymphocyte) or cytokine production. $^{33}$

Increase in paw size is a physical indicator of the inflammation in the onset as well as in the chronic phase of the disease. ${ }^{34}$ In this study, the arthritis induced rats developed a chronic swelling in multiple joints as a result of influence of inflammatory cells, erosion of joint cartilage, and bone destruction. It exhibited close similarities with rheumatoid disease seen in man. An increase in the paw volume after intra-dermal administration of the adjuvant reveals the status of arthritis. ${ }^{30}$ Effect of adjuvantinduced arthritis on Paw sizerats (Table 4) shows the anti-inflammatory effect of Olax subscorpioidea ethanol and aqueous root extracts at 400, 600 and $800 \mathrm{mg} / \mathrm{kg}$ bd wt respectively, on the changes in paw edema of induced untreated rats and treated animals. There was increase in paw size and redness developed over a $48 \mathrm{hr}$ period in the feet of experimental animals injected with chicken type 11 collagen - complete Freund's adjuvant. Swelling of the hind paw of adjuvant induced arthritic rats is seen in adjuvant induced arthritis rats. The arthritic rats are often relatively immobile due to severity of paw swelling. ${ }^{29}$ The Olax subscorpoidea aqueous and ethanol root extracts at different doses showed a marked reduction in paw size. However, the extracts decreased the paw volume by inhibiting the release of inflammatory mediators, showing its antiinflammatory effect in adjuvant induced arthritis. Increase in the size of the paw is a parameter used in the measurement of the anti-arthritic activity of different drugs administered in the treatment of inflammations. Increase in paw foot pad and tibio tarsal joint diameters in adjuvant induced arthritis rats could possibly be due to the delayed immunological upsurge in the disease. The influx of inflammatory cells in rats causes chronic swelling in many joints. The increase in swelling of the hind paw decreased significantly $(P<0.05)$ in the days that followed arthritis induction when compared to the untreated arthritic group. It can therefore be said that the likely mechanism for the reduction in paw size may be as a result of the suppressive effect of indomethacin and Olax subscoripoidea aqueous and ethanol root extracts. The phytochemical components present in the extracts such as alkaloids hinder antigen presentation and immune cells release while terpenoids regulate some cell to cell information transfer pathways that play a role in the course of inflammation for instance, nuclear transcription factor-kappaB (NF-kappaB). ${ }^{35}$ These actions of these and more phytochemical components may have caused the reversal in the continued increase in paw size of the arthritic rats. Our result agrees with another report where it was discovered that Olax subscorpioidea produced significant dose dependent inhibition of

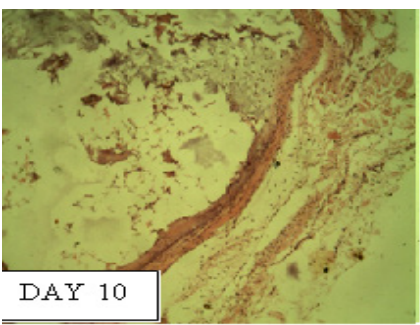

$\mathbf{A}$

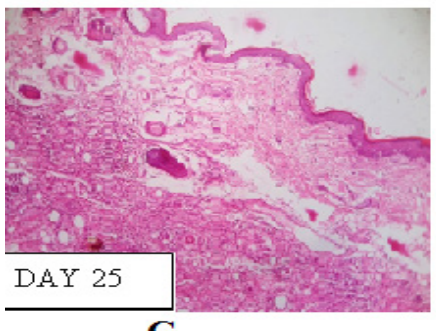

C

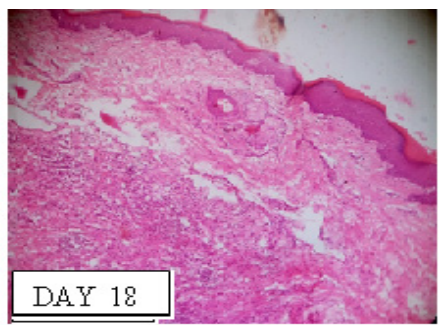

B

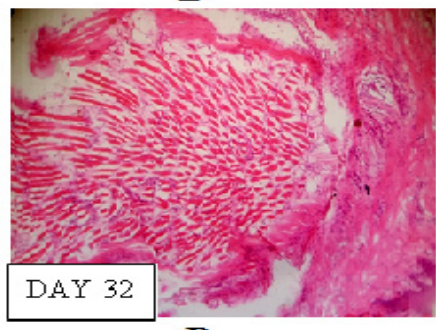

D
Plate 1 (A-D): Photomicrograph of joint of normal control rats (GP1) H\&E. mag. X100. (A)Thickened stratum corneum (SC) layer (white curve) and stratum granulosum (SG) (black curve), a clear cell layer (black arrow) and thick collagen fiber (star) (day 10). (B)Synovial lining cells (black arrow) (day 18). (C) A few number of multiple synoviocytes and giant cells (yellow arrow) at day 25 without evidence of inflammation (day 25).(D) Thick collagen fiber (white star) (day 32).

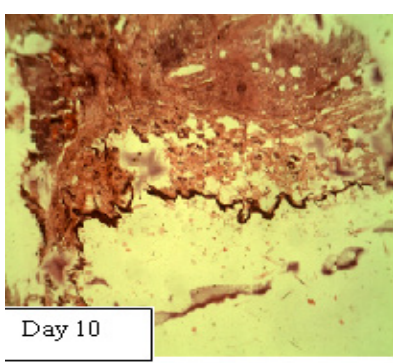

$\mathbf{A}$

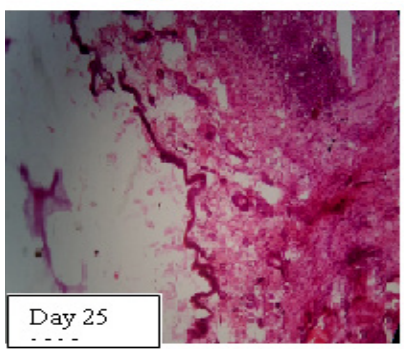

C

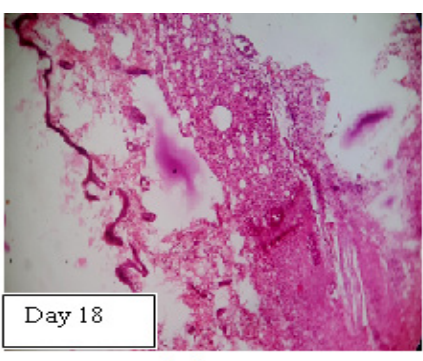

B

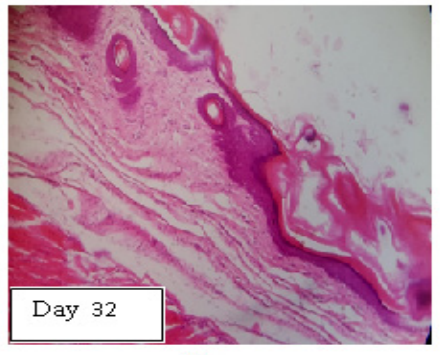

D
Plate 2 (A-D): Photomicrograph of positive control (GP 2) Rheumatoid tissue (induced but not treated). X100.

(A)Rheumatoid tissue result shows severe transmural oedema (star), destruction of the outer epidermis (double arrow) with irregular areas of necrobiosis on day 10. (B). Severe hyperplasia of synovial lining cells (SLC) (more than 15 SLC) keeping for acute inflammation and oedema (star). Destruction of outer epidemis and vacuolation (black arrow)onday 18. (C) Destruction of epidermal layer, loss of thickness and hyperplasia of synoviocytes (black arrow) on day 25. (D) Severe transmural oedema (star) with. Vacuolation is evident (black arrow). Epidermal layers destruction, hyperplasia of synoviocytes (black arrow) with the presence of synoviocytes (yellow arrow) on day 


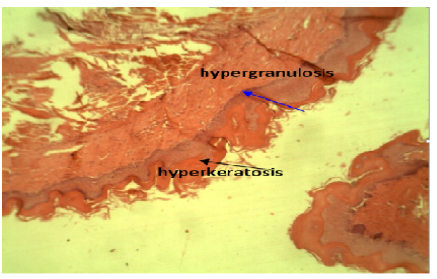

A

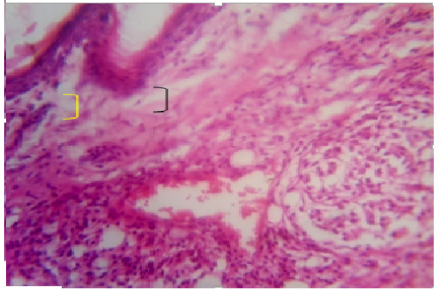

C

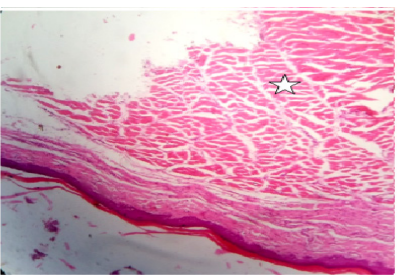

$\mathbf{B}$

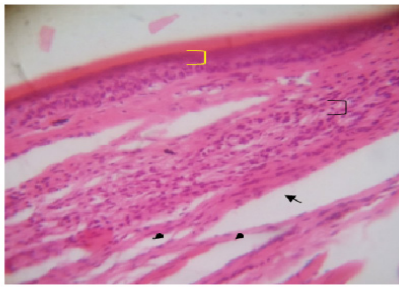

D

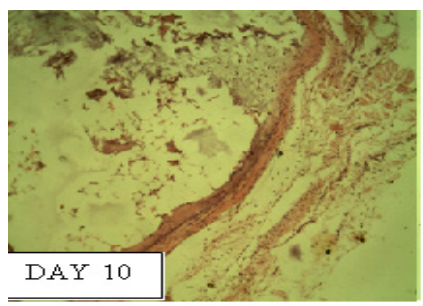

A

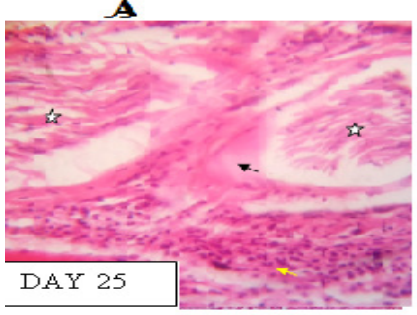

C
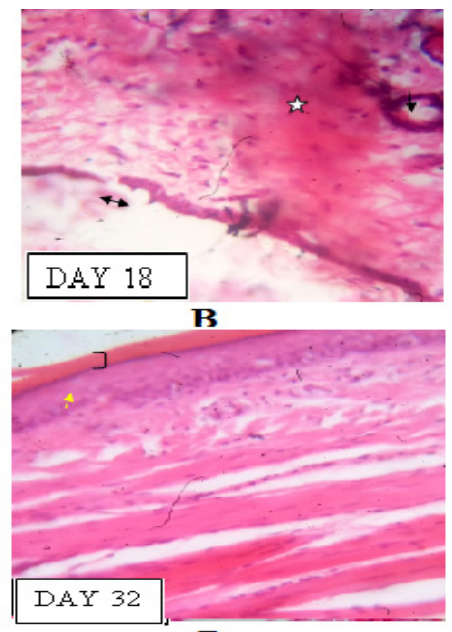

$\mathbf{D}$
Plate 3 (A-D): Photomicrograph of GP 3 Rheumatoid tissue treated with standard drug. H\&E. mag. X100.

(A)Severe fibrinoid necrosis (yellow arrow) on day 10, degeneration of stratum basale and lucidium (star). (B) Degeneration of stratum basale and lucidium (white star) few synoviocytes depicting decline of synovial lining cells hyperplasia at day 18 which led to reduced inflammation. (C) Quick onset of stratum corneum and stratum granulosum regeneration with intact collagen fibers (yellow arrow) and diffuse synoviocytes (white star) at the epidermal region is seen on days 25. (D) Stratum corneum and stratum granulosum regeneration (black star) with intact collagen fibers and diffuse synoviocytes (black star) at the epidermal region is seen on days32. The synoviocytes are reduced keeping for reduction in inflammation.

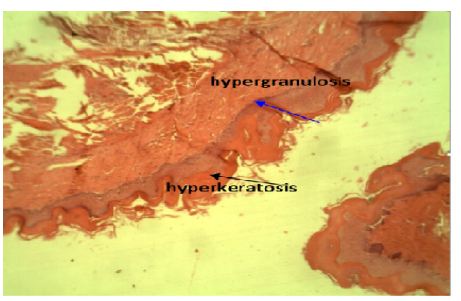

A

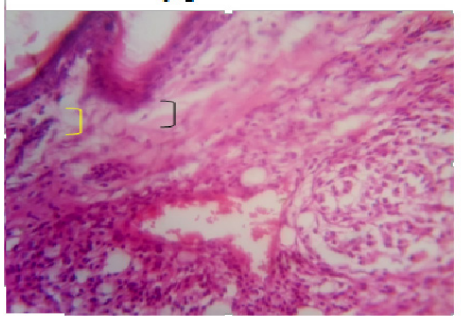

C

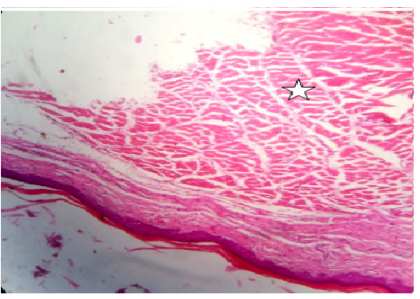

B

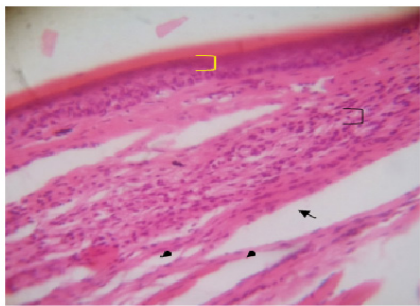

D

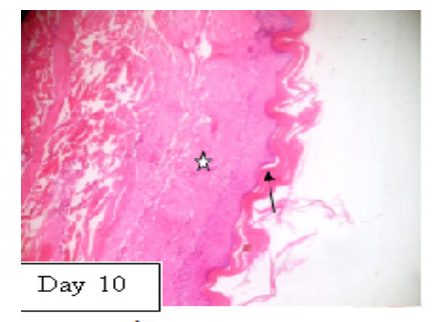

$\mathbf{A}$

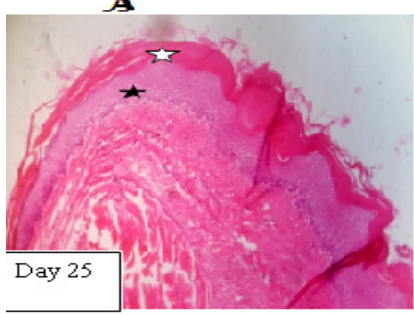

C

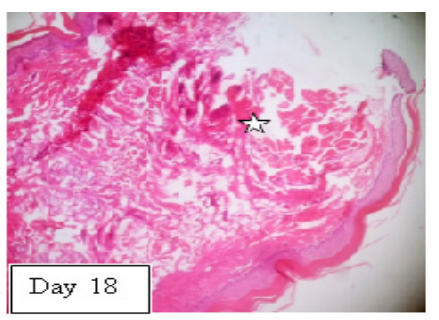

B

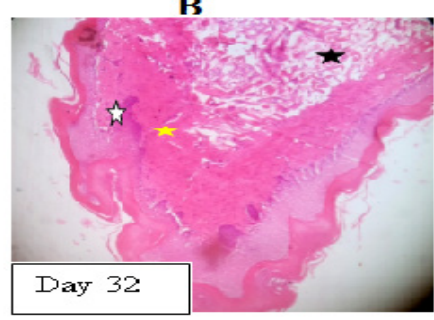

D
Plate 4 (A-D): Photomicrograph of GP 7 Rheumatoid tissues treated with $400 \mathrm{mg}$ Olax subscorpoidea aqueous extract. H\&E. mag. X100

(A) Photomicrograph of rheumatoid tissue showing intact stratum granulosum (yellow arrow) with increased thickness and rapidly regenerating stratum corneum (black arrow) and intact collagen fibers at the end of day 10. (B) The stratum granulosum rapidly regenerated with more increased thickness showing hypergranulosus (yellow arrow) with increased inflammatory cells (black arrow) at the end of day 18. (C)The stratum corneum(black arrow) and stratum granulosum (yellow arrow) completely regenerated with increased thickness keeping for hyperkeratosis and hypergranulosis, respectively on day 25. (D) There is also inflammatory infilterates mainly macrophages (short arrow) on day 32.
Plate 5: (A) Photomicrograph of GP 8 Rheumatoid tissue 600 mg Olax subthe end of day 10. (B) The oedema appeared reduced (star) with increased proliferation inflammatory cells mainly macrophages (yellow arrow) at the end of day 18. (C-D) The stratum corneum (black arrow) and granulosum (yellow arrow) appeared intact. (day 25 and 32)
Plate 6 (A-D): Photomicrograph of GP 9 Rheumatoid tissues treated with $800 \mathrm{mg}$ Olax subscorpoidea aqueous extract. H\&E. mag. X100.

(A) Acanthosis (star) and regeneration of the corneum (black arrow) were observed in the epidermal layer at the end of day 10. (B) Collagen fiber and epidermal layer regeneration with complete regeneration of the epidermal layers (white star) (day 18). (C) Collagen fiber and epidermal layer regeneration (white star), increased thickness together with collagen fiber distortion (black star) (day 25). (D) Reduced collagen fiber distortion (black star) on day 32 with no presence of synoviocytes showing reduced inflammation and an intact stratum corneum and granulosium (black and yellow stars) (day 32).. 


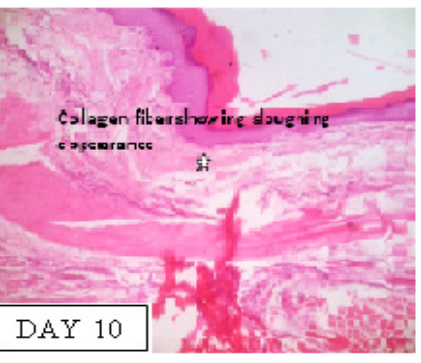

A

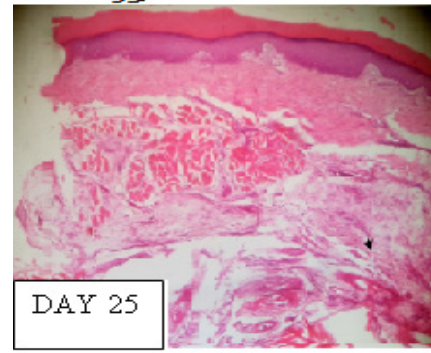

C

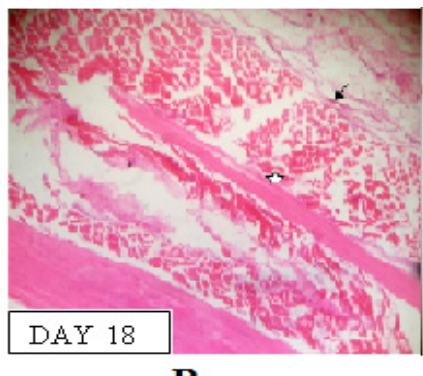

B

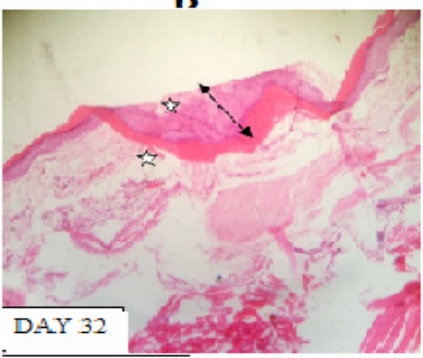

D

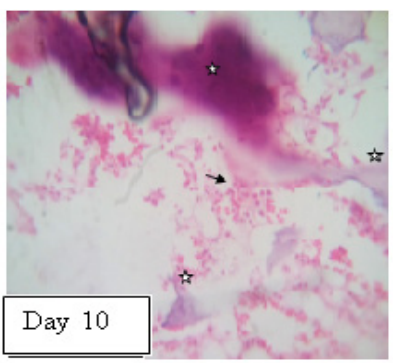

A

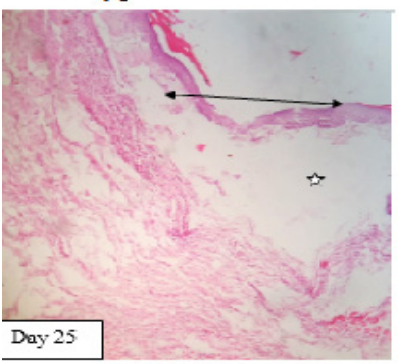

C

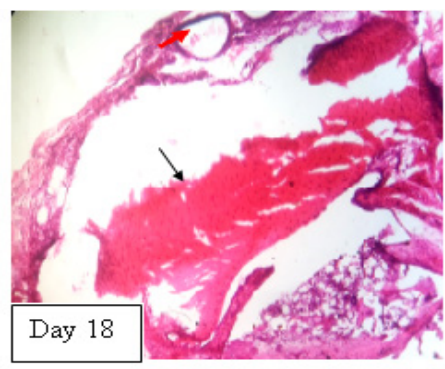

B

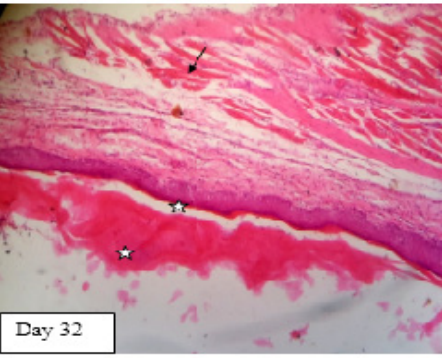

D

Plate 7 (A-D): Photomicrograph of GP 13 Rheumatoid tissue 400mg Olax subscorpoidea ethanol root extract. H\&E. mag. X100.

(A) Photomicrograph of rheumatoid tissue showing overlapping/or twisting of the stratum granulosum with corneum (arrow head) depicting regeneration process although the dermal region is destroyed (star) at the end of day 10. (B). Granulation tissue is evidence (star) with proliferation of inflammatory cells (arrow) at day 18 (C): hyperkeratosis and hypergranulosis and acanthosis are all visible on day 25 and 4 although the collagen fibers are intact but evidence of proliferation of inflammatory cells is also seen (back arrow) (day 25). (D) But on day 32, the collagen fibers is degenerated.

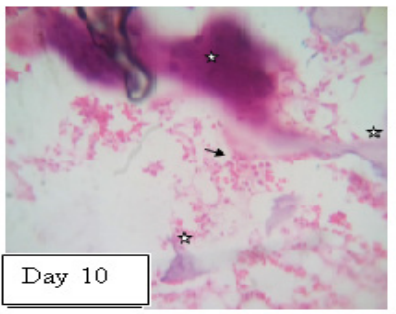

A

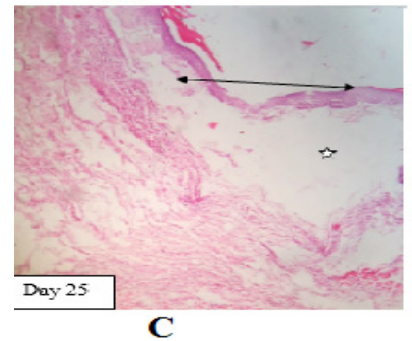

C

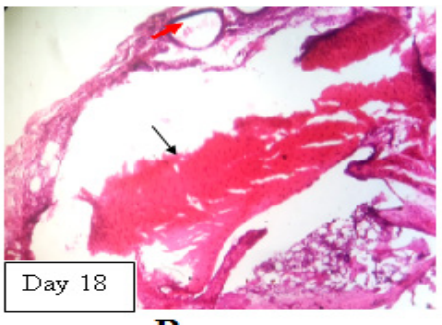

B

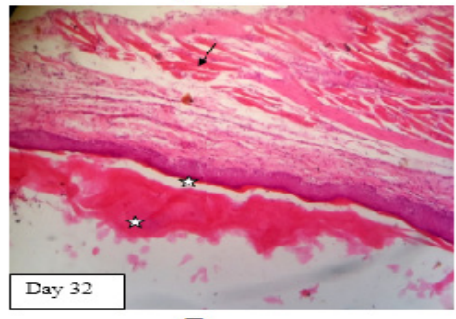

D

Plate 8 (A-D): Photomicrograph of GP 13 Rheumatoid tissue 600mg Olax subscorpoidea ethanol root extract. H\&E. mag. X100

(A) Photomicrograph of rheumatoid tissue showed destruction of dermal layers (black star), and collagen fiber (white star) at the end of day 10. (B) collagen fiber (star) and epidermal layer (arrow head) degeneration on day 18. (C) loss of collagen fiber and slight regeneration of the epidermal layer (arrow head) on day 25. (D): there is hyperkeratosis (white star) and hypergranulosis (black star) with erosion of dermal regions (red star) on day 32.

inflammation. Ismail et al. observed maximum inhibition at $400 \mathrm{mg} / \mathrm{kg}$. They related the effect of Olax subscorpioidea to their phytochemical constituents such as flavonoids, anthraquinones, saponins, cardiac glycoside and polyphenols. According to this report, saponins have before now reported to display anti-inflammatory activities. ${ }^{36}$

The C-reactive protein $(\mathrm{C}-\mathrm{RP})$ level in serum samples were found to be significantly $(P<0.05)$ higher in all arthritic rats than the normal control rat group as is seen in Table 5. C-reactive protein level is used to determine the rate of progression of disease. $\mathrm{C}-\mathrm{RP}$ is an acute phase protein which is synthesized in the liver under conditions of systemic inflammation. ${ }^{37}$ The synthesis of CRP is activated by the influx of synovial macrophages and fibroblasts by inflammatory cytokines including TNF- $\alpha$, IL-1, and especially IL- 6 .These cytokines are found to be synthesized in large amount in rheumatoid arthritis. ${ }^{38}$ The rise in serum C-RP levels was reversed by treatment with indomethacin (standard drug) and Olax subscorpioidea aqueous and ethanol root extracts at 400,600 and $800 \mathrm{mg} / \mathrm{kg}$ bd wt caused a significant $(P<0.05)$ reversal of the $\mathrm{C}$-reactive proteins to levels close to that found in the normal control rats. The phytochemical and other chemical constituents of the plant extract may have modulated the synthesis of other pro-inflammatory molecules there by inhibiting the pro-inflammatory cytokines such as IL-1 $\beta$, IL-6, TNF- $\alpha$ from different sources.

A rise in RF level in adjuvant diseases study of rheumatoid arthritis has been observed. The high titer values of rheumatoid factor (RF) was observed in the sera from individuals with rheumatoid arthritis (RA).$^{39}$ In this study, the arthritic rats had significantly $(P<0.05)$ elevated level of rheumatoid factor. However, treatment with varied doses of Olax 
subscorpioidea significantly $(P<0.05)$ decreased the level close to normal as is found in the normal control (Table 6). The effect of the extract was both time and dose dependent. Our result showed that the anti-inflammatory effects of Olax subscorpioidea could be as a result of the inhibition of B-cell action. B-cells activation is through toll-like receptors and other genetic factors that predispose organisms like the rats used in this study, leading to rheumatoid factor generation in arthritis. Rheumatoid factor (RF) is an antibody directed to determinants in the Fc portion of immunoglobin $G$ molecule. The ameliorative effect of our extracts could be attributed to the action of flavonoids, tannins, saponins and other phytochemical constituents present in their plants. ${ }^{40}$

Erythrocyte sedimentation rate is an indicator of a state of chronic inflammatory. ${ }^{41}$ In acute tissue damage, several factors such as tissue damage, inflammation and infection are increased which gives rise to chronic inflammation and chronic infection that may have played an important role in increased erythrocyte aggregation. ${ }^{42}$ raised CRP levels in rheumatoid arthritis plays an important role in the induction and maintenance of increased erythrocyte aggregation as is found in the blood of rheumatoid arthritis patients

Treatment of the arthritic rats with the plant extracts resulted in a timedependent reduction in ESR level (Table 7), with effect being more pronounced on day 32 of the study. Our result is in agreement with the result of the study done by Patel and Shar [2013]. ${ }^{41}$ An increased disease processes is indicated by an upsurge in ESR. In this study, the decrease in ESR denotes the anti-arthritic activity of the plant extracts and the standard drug.

Cytokines levels were measured in the arthritic and non arthritic serum samples. In comparison to the normal control group, the levels of TNF- $\alpha$, IL- $1 \beta$ and IL-6 were found to be significantly $(P<0.05)$ higher the arthritic rat groups in contrast to the normal control group. It is has been established that TNF- $\alpha$ increases proliferation and cytokine (IL- $1 \beta$ and IL-6) productions in immune cells infiltrating the joints. The presence of IL-6 activates the synthesis of acute phase proteins like C-reactive protein, fibrinogen and serum amyloid in the joints of arthritic patients. This elevation of level of IL-6 is correlated with clinical variables such as morning joint stiffness, number of joints affected and other laboratory variables such as erythrocyte sedimentation rate, C-reactive protein and rheumatoid factor titer. This action turns on the expression of the CRP- gene. This leads to the synthesis of C-reactive protein. ${ }^{43}$

The Cytokine levels in the arthritic rats decreased $(P<0.05)$ significantly following treatment with the plant extract whereas the cytokine levels in arthritic untreated rats continued to increase significantly $(P<0.05)$ till day 32 when the study was terminated. Within the treatment arthritic rats administered $800 \mathrm{mg} / \mathrm{kg}$ Olax subscorpiodea ethanol extract were found to be as effective as the indomethacine standard treated rats. Also observed that rheumatoid arthritis is caused by a number of inflammatory molecules released by macrophages and fibroblasts. Such molecules include IL- $1 \beta$, IL- 6 and TNF- $\alpha$, prostaglandins and reactive oxygen are responsible for the initiation of pain along with swelling of the limbs and joints, bone deformations and disability of joint function. ${ }^{44}$ Pro inflammatory cytokines produced by the inflamed synovium as well as by chondrocytes in the arthritic joints attributes of arthritic joints is the tend to persist, hence enforcing the continued inflammation. ${ }^{45}$

\section{Histological analysis of adjuvant induced arthritic rat joints}

Histopathological studies of the paw joints in the negative control group (normal rats) revealed normal joint structure Plate (1A-1D) with an intact cartilage and no distortions. However, the untreated arthritic rats (Plate 2A-2D) showed moderate to severe hyperplasia of synovium with focal cartilage destruction. It also showed a marked damage of articular structure which shows that there exist joint damage and inflammation. The arthritic treated groups (Plates 4-9) also showed moderate to severe rheumatoid tissue damage. But treatment of arthritic rats with Olax subscorpoidea (aqueous and ethanol) root extracts at 400, 600 and $800 \mathrm{mg} / \mathrm{kg}$ body weight and standard drugs (indomethacine) showed significant reduction in hyperplasia of synovium when compared to the induced but not treated group rats (Plates 3A-3D) during the course of treatment. The effectiveness of the plant extracts could be compared to that of the standard drug. This result shows that bones can re-form when treated with Olax subscorpoidea aqueous and ethanol root extracts and standard drugs (indomethacine). The potential of Olax subscorpoidea aqueous, ethanol root extracts and standard drug (indomethacine) to exhibit such therapeutic ability may imply that it is able to counter inflammation by suppressing the process, interfere with synovitis and protect the joint as desired in rheumatoid arthritis therapy. Both plants possess anti-arthritic potentials. The anti-arthritic effect of the plant extracts studied here could be due to the presence of the phytochemical constituents in the plants.

In conclusion, our results strongly support the anti-arthritic potential of ethanol and aqueous root extracts of Olax subscorpioidea in reversing the effect of adjuvant on the rats and its use by rural dwellers in the management of Rheumatoid arthritis. The observed effects are attributed to the presence of some active principles of Olax subscorpioidea such as flavonoides, alkaloids and phenols which have anti-inflammatory, anti-pyretic and anti-oxidant properties. However, it is paramount that further studies be carried out to identify and characterize the lead active compounds It is expected that further elucidation of the molecular mechanisms behind the action of these phytochemicals and evaluation of its anti-arthritis activities on human clinical trials.

\section{ACKNOWLEDGEMENT}

The authors are highly thankful to Tertiary Education Trust Fund (TETFUND) for providing the facilities in accomplishing this research work.

\section{CONFLICT OF INTEREST}

The authors declare no conflict of interests.

\section{ABBREVIATIONS}

T-cells: Thymus lymphocyte cells; B-cells: Bone marrow cells; Fc: Fra ment Crystallizable region.

\section{REFERENCES}

1. Scott DL, Wolfe F, Huizinga TW. Rheumatoid arthritis. Lancet. 2010;376:1094-8.

2. Visser H, Le Cessie S, Vos K, Breedveld FC, Hazes JM. How to diagnose rheumatoid arthritis early: a prediction model for persistent (erosive) arthritis Journal of arthritis and Rheumatology. 2002;46(2):357-65.

3. Rupp I, Boshuizen H, Jacobi C. Comorbidity in patients with rheumatoid arthritis: effect on health-related quality of life. Journal of Rheumatology. 2004;31(1):58-65

4. Jain R, Lipsky PE. Treatment of Rheumatoid Arthritis. Journal of Medical Clinic of North America. 1997;81(1):57

5. Breivik H, Collett B, Ventafridda V, Cohen R, Gallacher D. Survey of chronic pain in Europe: prevalence, impact on daily life and treatment. European Journal of Pain. 2006;10(4):287-333.

6. Dendooven A, De Rycke L, Verhelst X, Mielants H, Veys EM, De Keyser F. Leflunomide and methotrexate combination therapy in daily clinical practice. Annals of the Rheumatic Diseases. 2006;65(6):833-4.

7. Curtis JR, Singh JA. The use of Biologics in Rheumatoid Arthritis: Current and Emerging Paradigms of care. Journal of Clinical Therapeutics. 2011;33(6):679-707.

8. Santaglo S, Mutheeswaran S, Saravanan M, Chellappandian M, Gabriel P, et al. Ameliorative effect of 4 Drynaria quercifolia (L.), an ethnomedicinal plant, in arthritic animals. Food Chemical Toxicology. 2007;51:356-63.

9. Aiyeloja AA, Bello OA. Ethnobotanical potentials of common herbs in Nigeria. A case study of Enugu State. Journal of Educational Research and Review. $2006 ; 1(1): 16-22$ 
10. Mutiu IK, Ademola OA, Emmanuel M. Olax subscorpioidea Oliv. Leaf Alleviates postprandial Hyperglycaemia by inhibition of X-analyze and X-glucosidase. International Journal of Pharmacology. 2015;11(5):484-9.

11. Konan K, Justin NK, Lydie B, Souleymane M, Francis YA, David NJ. Hepatoprotective and in vivo antioxidant activity of Olax subscorpioidea Oliv. (Olacaceae) and Distemonathus benthamianusBaill. (Caesalpiniaceae). Pharmacognosy Magazine. 2015;11(41):111-6.

12. Adegoke E, Akinsanya A, Nagu A. Studies of Nigerian Medicinal Plants. A preliminary survey of Plant Alkaloids. Journal of West Africa Science Association. 1968;13:13-39.

13. Moudgil KD, Kim P, Brahn E. Advances in Rheumatoid Arthritis Animal Models. Current rheumatology reports. 2011;13(5):456-63.

14. Pearson CM. Development of arthritis, periarthritis and periostitis in rats given adjuvant. Proceedings of the Society for Experimental Biology and Medicine. 1956;91(1):95-101.

15. Trease GE, Evans WC. Text book of pharmacology, $12^{\text {th }}$ edition English Language Book Society, Bailliere, Tindall Publication, London. 1993;343-83.

16. Sofowora AE. Medicinal plants and traditional medicine in Africa. 2nd edition. Spectrum Book Ltd. Ibadan Nigeria. 1993.

17. AOAC. Official Methods of Analysis. Howitz edition. 1980;734-40.

18. Westergren A. Diagnostic tests: the erythrocyte sedimentation rate range and limitations of the technique. Triangle. 1957;3(1):20-5.

19. C-Reactive Protein in Serum National Health and Nutrition Examination Survey (NHANES 2007-2008.

20. Otten HG, Daha MR, DERooij HH, Breedveld FC. Quantitative detection of class-specific rheumatoid factors using mouse monoclonal antibodies and the biotin/streptavidin enhancement system. British Journal of Rheumatology. 1998;28(4):310-6.

21. Bienvenu JAD, Monneret G, Gutowski MC, Fabien N. Cytokine assays in human sera and tissues. Toxicology. 1998;129(1):55-61.

22. Ismail OI, Akiwumi SM, Temidajo DP, Abiodun ML. Antinociceptive and antiinflammatory effects of Olax subscorpioidea Oliv. Leaf extract in rodent: possible mechanisms of antinociceptive action. West African Journal of Pharmacy. 2015;26(1):99-112.

23. Konan K, Justin NK, Lydie B, Souleymane M, Francis YA, David NJ. Hepatoprotective and in vivo antioxidant activity of Olax subscorpioidea Oliv.(Olacaceae) and Distemonathus benthamianus Baill. (Caesalpiniaceae). Pharmacognosy Magazine. 2015;11(41):111-6.

24. Rheumatoid arthritis. Centers for Disease Control and Prevention Web site. Updated November 6, 2014. Accessed March 9. 2015.

25. Handout on health: Rheumatoid arthritis. National Institute of Arthritis and Musculoskeletal and Skin Diseases Web site. Published August 2014. Accessed March 9, 2015

26. Kumar P, Banik S. Pharmacotherapy Options in Rheumatoid Arthritis. Journal of Clinical Medicine Insights Arthritis and Musculoskeletal Disorders. 2013;6:35-43.

27. Emery P. Treatment of rheumatoid arthritis. British Medical Jounal. 2006;332(7534):152-5

28. Lina A, Mary AF, Gary JB, Alfredo RS. Imaging Studies in Freund's Complete Adjuvant Model of Regional Polyarthritis, a Model Suitable for the Study of Pain Mechanisms, in the rats. American College of Rheumatology Arthritis and Rheumatism. 2007;63(6):1573-81.

29. Bendele AM. Animal models of rheumatoid arthritis. Journal of Musculoskeletal and neuronal Interaction. 2001;1(4):377-85.

30. Mondal P, Das S, Mahato K, Borah S, Junejo JA, Zaman K. Evaluation of AntiArthritic Potential of the HydroAlcoholic Extract of the Stem Bark of Plumeria
Rubra in Freund's Complete AdjuvantInduced Arthritis in Rats. International Journal of Pharmaceutical Science Research. 2016;7(9):3675-88.

31. Roubenoff R, Freeman LM, Smith DE, Abad LW, Dinarello CA, Kehayias JJ. Adjuvant arthritis as a model of inflammatory cachexia. Journal of Arthritis and Rheumatism. 1997;40(3):534-9.

32. Lecker SH. Pathway (Ubiquitin-protein ligases in muscle wasting: multiple paralled pathways. Current opinion in clinical nutrition and metabolic care. 2003;6(3):271-5

33. BellikY, Boukraâ L, Alzahrani HA, Bakhotmah BA, Abdellah F, Hammoudi SM, et al. Molecular mechanism underlying anti-inflammatory and anti-allergic activities of phytochemicals: an update. Molecules. 2012;18(1):322-53.

34. Andersen ML, Santos EH, Seabra MDL, Silva DA, Tufik S. Evaluation of acute and chronic treatments with Harpagophytum procumbens on Freund's adjuvant-induced arthritis in rats. Journal of Ethnopharmacology. 2004;91:325-30.

35. Salminen M, Lehtonen T, Suuronen K, Kaarniranta K, Huuskonen J. Terpenoids: natural inhibitors of NF-kB signaling with anti-inflammatory and anticancer potential. Journal of Cellular and Molecular Life Sciences. 2008;65:2979-99.

36. Ismail OI, Akiwumi SM, Temidajo DP, Abiodu ML. Antinociceptive and anti-inflammatory effects of Olax subscorpioidea Oliv. Leaf extract in rodent: possible mechanisms of antinociceptive action. West African Journal of Pharmacy. 2015;26(1):99-112

37. Portanova JP, Zhang Y, Anderson GD, Hauser SD, Masferrer JL, Seibert K, et al. Selective neutralization of prostaglandin E2 blocks inflammation, hyperalgesia, and interleukin 6 production in vivo. Journal of Experimental Medicine. 1996;184(3):883-91.

38. Brull DJ, Serrano N, Zito F, Jones L, Montgomery HE, Rumley A, et al. CRP gene polymorphism influences CRP levels: implications for the prediction and pathogenesis of coronary heart disease. Arteriosclerosis, Thrombosis and Vascular Biology. 2003;23(11):2063-9.

39. Waaler E. On the occurrence of a factor in human serum activating the specific agglutination of sheep corpuscles. Acta Patholology and Microbiologyu Scand. 1940;17:172-96.

40. Mohamed MA, Mahmoud MF, Rezk AM. Effect of pentoxifylline and pioglitazone on rheumatoid arthritis induced experimentally in rats. Menoufia Medical Journal. 2014;27:766-74.

41. Patel SS, Shah PV. Evaluation of anti-inflammatory potential of the multidrug herbomineral formulation in male Wistar rats against rheumatoid arthritis. Journal of Ayurveda and Integrative Medicine. 2013;4(2):86-93.

42. Dorner T, Egerer K, Feist E, Burmester GR. Rheumatoid factor revisited. Current Opinion on Rheumatology. 2004;16(3):246-53.

43. Hietala MA, Nandakumar KS, Pearson L, Fahlen S, Holmdahl R, Pekna M Complement activation by both classical and alternative pathways is critical for the effector phase of arthritis. European Journal of Immunology. 2004;34:1208-16.

44. Kshirsagar AD, Panchal PV, Harle UN, Nanda RK, Shaikh HM. Anti-inflammatory and antiarthritic activity of anthraquinone derivatives in rodents. International Journal of Inflammation. 2014.

45. Ainola MM, Mandelin JA, Liljestrom MP, Li TF, Hukkanen MV, Konttinen YT. Pannus invasion and cartilage degradation in rheumatoid arthritis: involvement of MMP-3 and interleukin-1 $\beta$. Journal of Clinicaland Experimental Rheumatology. 2005;23:644-50.

\section{GRAPHICAL ABSTRACT}

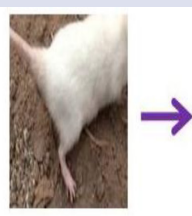

Before induction of

Arthritis with

CFACChicken type11

Collagen

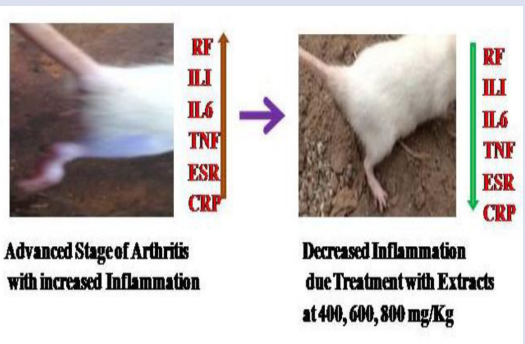

\section{SUMMARY}

- The observed anti-arthritic effects of Olax subscorpioidea aqueous and ethanol root extracts are attributed to the presence of some active principles of Olax subscorpioidea such as flavonoides, alkaloids and phenols which have anti-inflammatory, anti-pyretic and anti-oxidant properties. However, it is paramount that further studies be carried out to identify and characterize the lead active compounds It is expected that further elucidation of the molecular mechanisms behind the action of these phytochemicals and evaluation of its antiarthritis activities on human clinical trials.

Cite this article: Ezeani NN, Ibiam UA, Orji OU, Igwenyi IO, Aloke C, Alum E, Aja PM, Effects of Aqueous and Ethanol Root Extracts of Olax subscopioidea on Inflammatory Parameters in Complete Freund's Adjuvant-Collagen Type II Induced Arthritic Albino Rats. Pharmacog J. 2019;11(1):16-25. 